\title{
Factors influencing the production of oilseed crops among smallholder farmers in Limpopo Province
}

\author{
Priscilla Ntuchu Kephe ${ }^{1,2, *}$, Kingsley K. Ayisi ${ }^{2}$, Brilliant Mareme Petja ${ }^{1,2,3}$, Adlet Phophi Mulaudzi ${ }^{2}$ \\ and Kabisheng Emmanuel Mabitsela ${ }^{2}$ \\ ${ }^{1}$ Department of Geography and Environmental Studies, University of Limpopo, Polokwane, South Africa \\ 2 Risk and Vulnerability Science Centre, University of Limpopo, Sovenga, South Africa \\ ${ }^{3}$ Water Research Commission, Pretoria, South Africa
}

Received 17 April 2020 - Accepted 5 July 2020

\begin{abstract}
Smallholder farmers in rural communities that are prevalent in provinces such as Limpopo are not only confronted with the challenges of their direct environment but they also face new challenges in terms of the type of crops to produce in the era of climate change and variability. These challenges influence the way farmers make key decisions. Given that agricultural practices affect more than the farming unit, it is of interest to understand farmers' behaviour. A survey was carried out across agroecological zones in Limpopo. Six hundred farmers were interviewed to establish key factors underlying their choice of oilseeds to produce. Descriptive statistics and factor analysis were used to analyse the data. Results showed that the choice of crops to produce was influenced by socioeconomic and climatic factors. Factor analysis indicated that floods were the most influential factor in the choice of oilseeds. This was followed by implements, temperature, rainfall, cash, irrigation equipment, input availability and food security. Determining factors varied amongst farmers producing groundnut, soybean and sunflower. Farmers were more hesitant to cultivate sunflower and soybean primarily because of the lack of familiarity with these crops and this in turn magnified the risk created by the uncertainty surrounding the future financial returns from these crops. Further results highlight concerns about resource and input availability in the area. The provision of support in terms of inputs availability, implements, the development of reliable networks for information dissemination and training of oilseed farmers beyond their local environment and sphere is critical. This is particularly so given there is a host of site-specific factors that have a bearing on the farmers' decisionmaking processes. Stakeholders therefore need to take into account the variation in factors influencing farmers' decisions, and put in place site specific measures to properly guide farm management choices.
\end{abstract}

Keywords: climatic factors / food production / oilseed / planting choice / socioeconomic

Résumé - Facteurs influençant la production de cultures oléagineuses chez les petits exploitants agricoles de la province de Limpopo. Les petits exploitants des communautés rurales qui sont répandues dans des provinces comme le Limpopo sont non seulement confrontés aux défis de leur environnement direct, mais ils doivent également relever de nouveaux défis en termes de type de cultures à produire à l'ère du changement climatique et de sa variabilité. Ces défis influencent la manière dont les agriculteurs prennent des décisions importantes. Étant donné que les pratiques agricoles n'affectent pas seulement l'unité agricole, il est intéressant de comprendre le comportement des agriculteurs. Une enquête a été menée dans les zones agroécologiques du Limpopo. Six cents agriculteurs ont été interrogés afin d'établir les facteurs clés qui sous-tendent leur choix de production de graines oléagineuses. Des statistiques descriptives et une analyse factorielle ont été utilisées pour analyser les données. Les résultats ont montré que le choix des cultures à produire était influencé par des facteurs socioéconomiques et climatiques. L'analyse des facteurs a montré que les inondations étaient le facteur le plus influent dans le choix des graines oléagineuses. Viennent ensuite les outils, la température, les précipitations, l'argent, le matériel d'irrigation, la disponibilité des intrants et la sécurité alimentaire. Les facteurs déterminants variaient entre les agriculteurs produisant des arachides, du soja et du tournesol. Les agriculteurs étaient plus hésitants à cultiver le tournesol et le soja, principalement en

*Correspondence: kprissy@gmail.com 
raison du manque de familiarité avec ces cultures, ce qui a amplifié le risque créé par l'incertitude entourant les futurs rendements financiers de ces cultures. Il est essentiel d'apporter un soutien en termes de disponibilité des intrants, de mise en œuvre, de développement de réseaux fiables pour la diffusion d'informations et de formation des producteurs d'oléagineux au-delà de leur environnement et de leur sphère locale. Cela est d'autant plus important qu'il existe une multitude de facteurs spécifiques au site qui ont une incidence sur les processus de décision des agriculteurs. Les parties prenantes doivent donc tenir compte de la variation des facteurs qui influencent les décisions des agriculteurs et mettre en place des mesures spécifiques aux sites agricoles pour orienter correctement les choix de gestion des exploitations.

Mots clés : facteurs climatiques / production alimentaire / oléagineux / choix de plantation / socioéconomique

\section{Introduction}

Globally, agriculture plays an important role in the development of most emerging economies through its impact on the overall economic growth, household income generation and food security (Dube, 2016). In South Africa, agriculture supports the livelihoods of about $78.5 \%$ of the rural population, with most of them classified as smallholder and emerging farmers (DAFF, 2012). South African agriculture can be best described as a dual system whereby well-developed and capital-intensive commercial agriculture players contribute significantly to national food security. The second type of agriculture is the less developed and less-resourced agriculture undertaken by smallholder farmers and subsistence farmers. The crops grown by smallholder farmers can be grouped into plantation crops (e.g. sugar cane, coffee, tea), horticultural crops (fruits and vegetables), and field crops (e.g. maize, wheat, cotton, sunflower, sorghum, millets, groundnuts, cowpeas, soybeans). For instance, in recent years, maize has been the largest contributor (48\%) towards the gross value of field crops in South Africa, followed by sugarcane (13\%), wheat (11\%) and sunflower seed (7\%) (Schulze and Durand, 2016).

Farmers are the main land managers and their production decisions crucially affect crop outputs (Liu et al., 2019a, $2019 b$ ). The choice of what type of crop to farm in a particular area influences other variables such as output benefits (e.g. yields) (Zhang et al., 2016). It further affects the maintenance and quality of the farmland (Paul et al., 2017), as well as the ecological preservation of the environment (Wauters and Mathijs, 2014; Wang et al., 2017). Moreover, the development and utilization of resources in rural areas, evolution of agricultural landscape patterns, and sustainable development of rural areas (Krupnik et al., 2017) among others, are also affected. In the past, the production activity of farming households was determined by family consumption and food security, with the main economic objective being to meet household needs rather than of the pursuit of profitmaximization through market sales (Huang, 1986). However, more and more farming households are currently not only producing for consumption but also with the aim of optimizing production in order to maximize sales and profitability (Yang et al., 2017). Therefore, in analyzing agricultural production and management, the question of what to produce cannot be separated from the overall management objectives of the farmers. Understanding the motivations and factors underlying farmers' decision-making is fundamental to the development and implementation of agricultural policies. With these concerns in mind, it is important to study the factors influencing farmers' decision to produce oilseed crops.

The agricultural production activities of farmers especially that of subsistence and smallholder farmers are currently the main focus areas of many studies in Africa in general and South Africa in particular (e.g. Baiphethi and Jacobs, 2009; Mukwevho and Anim, 2014; Thamaga-Chitja and Morojele, 2014; Khapayi and Celliers, 2016). Several studies have examined the factors that affect farmers' crop-planting behavior. Such studies include that of Navarrete and Le Bail (2007), who found that agronomic characteristics such as soil and climate directly affected the crops as well as the varieties farmers planted. This confirms the earlier studies of Saito et al. (2006), who found out that in Laos, glutinous rice, which is a staple food of the area, tends to be planted on good soils, while cash crops and non-glutinous rice were cultivated on poor soils. Ravnborg and Rubiano (2001) also found soils to be an influencer in the decision of what to produce by farmers. Seo and Mendelsohn (2008) on their part found that, in South America, farmers are more likely to plant vegetables and fruits in warmer areas and potatoes and wheat in cooler regions. Additional factors that influence farmers' decisions include the regional advantages and the natural conditions of the farmland (Lawas and Luning, 1998); crop yields, resistance to pests, diseases, drought, and maturity dates (Dury et al., 2013). It was reported that in Haiti, some crops have special diseases, pests, or fertility requirements that make their production difficult or too risky (Jaffe, 1989) thereby making farmers more inclined to choose to farm insect-resistant and disasterresistant crops. Asrat et al. (2010) on their part reported that yield stability is an important attribute for farmers' choice of the crop in Ethiopia. The availability of water resources and current irrigation conditions (Henderson et al., 2017), transport availability and convenience (Liu, 2000) are other factors considered. Numerous studies suggest farmers' personal factors such as the farmers' ages (Negatu et al., 2016), household types (Chen et al., 2006), the family dependency ratio (Low, 1986) could all determine farmers' planting choices. Economic factors like the age-composition of the labor force (Greig, 2009), the agricultural income ratio (Arunrat et al., 2017), the characteristics of the market economy where farmers are willing to grow crops that have a predictable market price and are easy to sell (Jaffe, 1989; Haile et al., 2014; Wu et al., 2015; Mahon et al., 2016). Katundu et al. (2014) showed that, in Tanzania, the lower input costs involved in the production of groundnut was the main driving 
force behind groundnut becoming the third most important crop. Furthermore, the existing national policies in place $(\mathrm{Wu}$ et al., 2008) also play a role in crop choices. For example, Popescu et al. (2016) found the land policy applied in the Central and Eastern European Countries (CEECs) impacted on the farm crop choice. Yu et al. (2016) also pointed out that, after the 2014 Farm Bill, peasants expanded insured crops cultivation and, while in China, a $1 \%$ increase in the grain subsidy caused a $0.096 \%$ increase in grain crop acreage $(\mathrm{Wu}$ and Cai, 2010).

In South Africa, the government through various policies and schemes aims to upscale food security, especially amongst resource-poor farmers. The overarching question that needs to be unraveled could, therefore, be "what are the factors that influence the decision to produce grain crops in the summer rainfall areas of Limpopo Province?". According to Liu et al. (2019a, 2019b), factors affecting a Farmers' decisions to produce a certain crop are complex given that factors affecting such decisions range from individual characteristics to external drivers.

Given the natural structure of the agricultural sector, the challenges climate change is projected to have on the production of crops amongst smallholder and emerging farmers in South Africa due to their geographic location, low social and economic capacity to adapt to the impact of climate change (Pereira, 2017), it is critical that farmers choose the most appropriate crop to produce. It has been seen that smallholder farmers in rural communities have very limited accessibility to capital and technology, information, proper public infrastructure like roads, long-term weather forecasts and extension services (DAFF, 2012). Therefore, an understanding of what guides the investment decisions of smallholder farmers in terms of what crops to produce will engender a better understanding of how these farmers choose which crops to produce.

Existing studies in South Africa have focused mainly on factors affecting crop production amongst priority crops such as maize and, in so doing, paid less attention on exploring oilseed production decision determinants. Further review of literature provides scant evidence of an assessment of factors influencing the choice of crop for production, thereby calling for this paper to provide some necessary inputs towards this venture. Thus, to fill the gap, this paper studied the factors that impact the farmers' decision to produce oilseeds in Limpopo. It was fitting for this study to assess the physical and socioeconomic factors that could have impacted the choice of crops to produce by farmers. A better understanding of specific factors that influence farmer's choices is crucial in order to effectively prepare policies, development strategies, programmes and models aimed at supporting and enhancing the agricultural productivity of oilseeds.

An insight into the determining variables that guide smallholder farmers' production decisions will enable policymakers to enhance and develop policies and strategies that could help smallholder farmers to choose more appropriate crops for production, increase crop yield as well as cope and adapt to issues of climate variability. A deeper understanding of smallholder farmers' crop production investment decisions would enhance the development strategies and interventions necessary to ensure a successful production.

\section{Materials and methods}

\subsection{Study site}

The study was conducted in the agroecological zones of Limpopo Province (Fig. 1). The entire province covers an area of 12.46 million hectares, which is $10.2 \%$ of the total area of South Africa (Oni et al., 2012). Climatic regions in the area include the Lowveld (arid and semi-arid) regions, the middle veld, Highveld, semi-arid region the escarpment region which has a sub-humid climate with a $700 \mathrm{~mm}$ rainfall per annum (LDA, 2012). Rainfall in the province is mostly received between October and April and ranges from $200 \mathrm{~mm}$ in the hot dry areas to $1500 \mathrm{~mm}$ in the high rainfall areas. There is high annual rainfall variability in the province. This has an impact on the water balance of the region and will consequently affect those dependent on agriculture. Climatic variation in the province allows this province to produce a range of agricultural products. Agriculture is seen as a cornerstone of the province's economy and has been earmarked as one of the economic priority areas for development in the province by the Provincial Government (Botha, 2006). However, there are two types of agricultural production systems taking place in Limpopo province (Oni et al., 2012): large-scale commercial farming on the one hand and smallholder farming systems on the other.

\subsection{Sampling design}

Purposive sampling is a non-probabilistic sampling method (Trochim, 2006). It was used in this study to target a specific sample. In selecting a suitably representative sample, the researcher followed a two-stage sampling process. The first stage involved selecting the survey area. Limpopo Province was selected for the study because it had different agroecological zones (AEZ), which represented variation in the landscape. In the province, farming practices comprise mainly of rain-fed agriculture and there is a good number of smallholder farmers. The second stage in the sampling process involved selecting the total available smallholder farmers who are engaged in oilseed production in the area. According to Statistics South Africa (2012), the country lacks information on smallholder and subsistence agriculture. Agricultural censuses and surveys have largely concentrated on commercial agriculture and have ignored small-scale and subsistence agriculture (Statistics South Africa, 2010, 2012), thereby making it difficult to get a correct figure of the total number of subsistence/smallholder farmers in the survey area.

A criterion was developed to select the participating sample set as follows: the respondents had to be individual smallholder farmers, practicing crop production and are solely dependent on rainfall for production. Relevant departments in each local municipality supplied a list fitting the stated criteria and smallholder farmers were randomly selected from bases on agro-ecological zones in Limpopo. The sampling was used to assess uniformity and homogeneous characteristics that meet the objectives of the study. These characteristics had to adhere to the statistical specifications for accuracy and representatively. A representative sample was selected from each AEZ using a purposive sampling procedure. 


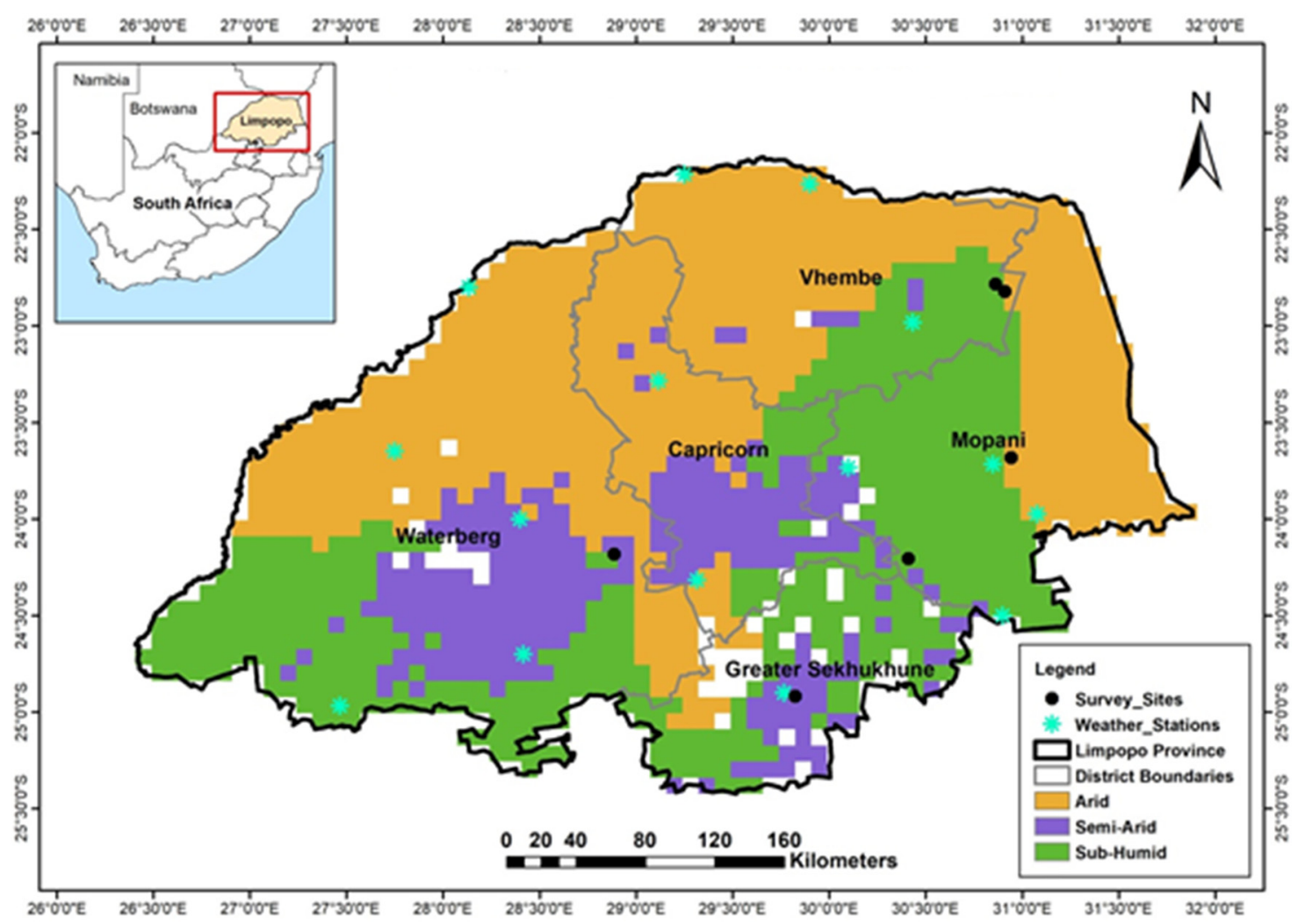

Fig. 1. Location map of Limpopo showing agro-ecological zones (AEZ) and sample sites.

Source: adapted from Harvest Choice, 2010.

\subsection{Data collection}

The data collection method involved the use of a survey research design for this study. Questionnaires were used to collect data. According to Tuckman (2000) and Van Niekerk (2002), questionnaire survey methods make it possible to measure what a person knows and the type of information he/ she has, the values and beliefs of the person and the attitudes towards what the questionnaire is about. The questionnaire was relevant to the aims of the study and the respondents involved in the study.

The questionnaire was pre-tested to minimize errors and format unclear questions. Farmers interviewed during the pretesting were not included in the final selected participants for this study. Respondents were selected based on their willingness to participate in the research. A total of 600 farmers were interviewed by trained enumerators obtaining verbal consent.

The questionnaire consisted of several sections with section B focusing on agronomic practices and crop production. Question B16 looked at the crop production factors influencing investment decisions contained questions on demographic characteristics and socioeconomic factors. Questions were designed in English but translated into the languages understood by the participants during the interviews and focus group discussions. This was to make sure the farmers understood the questions and be able to express their views. The respondents were asked to select the factors that influenced their decisions to produce certain selected oilseed crops. A response rate of $100 \%$ was achieved since all sampled farmers were interviewed by the research team.

\subsection{Data analysis}

In order to assess the factors influencing the choice of oil seeds produced by the farmers, descriptive statistics and factor analysis were used to analysed collected data. Descriptive statistics, such as frequencies, were used since they allowed for the strategies to be ranked in terms of numbers of farmers being influenced by a particular factor. Factor analysis was used to group correlated strategies into one group for easier analysis and interpretation of results. The factor analysis was to determine the factors that contributed most to influencing the farmers' choices of crops to produce.

\section{Results}

\subsection{The situation of oil seeds planting in Limpopo}

Oilseed crops planted in Limpopo are mainly soybean, sunflower and groundnut. Results from the survey showed that farmers planted groundnuts the most, followed by sunflower and lastly soybean. More farmers planted a combination of sunflower and groundnut. No farmer planted all three oilseed crops (Fig. 2). 


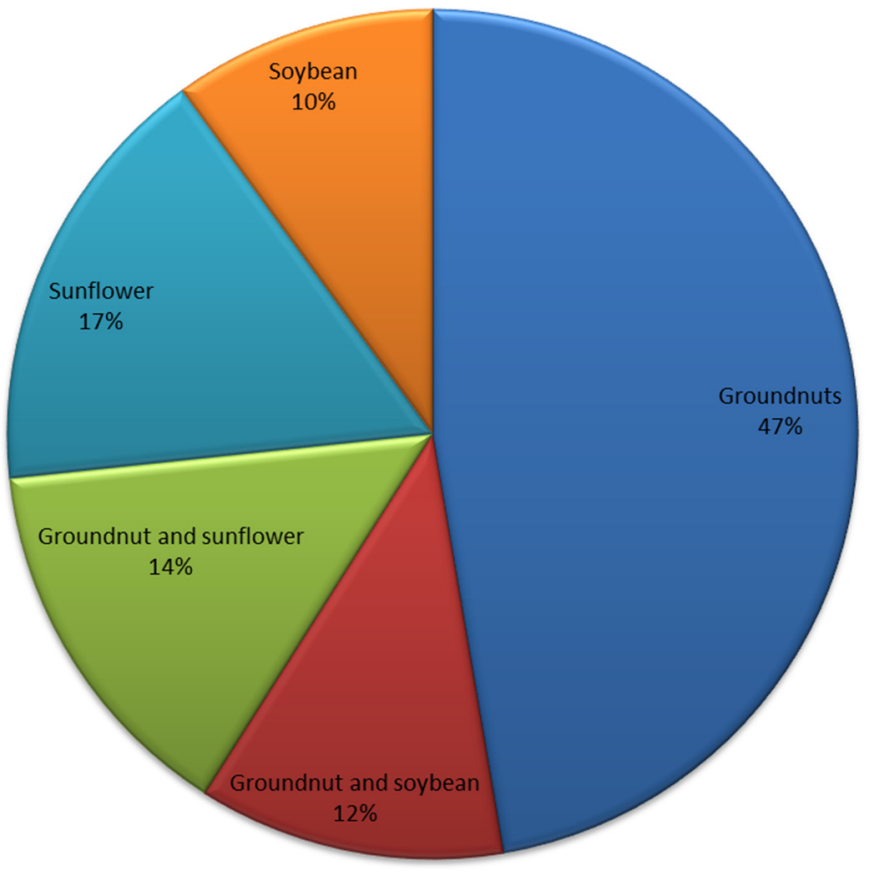

Fig. 2. Percentage of surveyed farmers cultivating groundnut, soybean, and sunflower in Limpopo Province.

Table 1. Factor loadings for crop investment decision in Limpopo Province.

\begin{tabular}{llrr}
\hline Factor pattern & F1 & \multicolumn{1}{l}{ F2 } & \multicolumn{1}{c}{ F3 } \\
\hline Food security & $\mathbf{0 . 7 3 3}$ & 0.332 & -0.593 \\
Floods & $\mathbf{0 . 9 2 7}$ & 0.181 & 0.329 \\
Implements & $\mathbf{0 . 8 9 9}$ & 0.297 & 0.321 \\
Irrigation equipment & $\mathbf{0 . 8 1 5}$ & -0.358 & 0.456 \\
Rainfall & $\mathbf{0 . 8 6 4}$ & -0.460 & -0.205 \\
Temperature & $\mathbf{0 . 8 8 9}$ & -0.431 & 0.154 \\
Draft power & 0.577 & $\mathbf{0 . 6 4 9}$ & 0.496 \\
Labour & 0.429 & $\mathbf{0 . 8 8 8}$ & -0.166 \\
Input availability & 0.574 & 0.381 & $-\mathbf{0 . 7 2 5}$ \\
Cash & $\mathbf{0 . 8 3 4}$ & -0.456 & -0.310 \\
Water (irrigation) & 0.207 & $-\mathbf{0 . 9 6 8}$ & -0.142 \\
Cronbach's alpha & $\mathbf{0 . 8 9 9}$ & & \\
\hline
\end{tabular}

\subsection{Factors influencing decisions for investments}

The decision to produce soybean, groundnut, and sunflower is influenced by either constraining factors or non-constraining factors. The respondents were asked about the factors that influenced their investment decisions in producing groundnuts, soybean, and sunflower. Their responses as seen from Figure 3 showed that the decisions to produce groundnuts are strongly influenced by factors such as the availability of cash (98\%), rainfall (97\%), input availability $(97 \%)$, food security $(91 \%)$ and temperature $(89 \%)$. The most constraining factors influencing soybean production are input availability $(58 \%)$, cash availability
(56.83\%) labour (54\%), rainfall, water (irrigation) (48.83\%), food security (43\%) and temperature (49\%). Sunflower is the least favored crop in the area in terms of investment decisions. Most of the factors that influence production are more of constraining factors of production. The only factor which is not a constraint to sunflower production is water.

\subsection{Factor analysis}

Factor analysis was carried out to determine which factors are most important to the farmers when making a crop investment decision. The result from Table 1 shows that floods, implements, temperature, rainfall, cash, irrigation equipment, and food security were the major factors that influenced the farmers' decision on investment.

\section{Discussion}

The decision-making process underlying crop choice is very complex as has been reflected in the relevant literature on the subject (e.g. Liu et al., 2019a, 2019b; Kinuthia et al., 2018). In terms of the factors underlying crop investment decisions as shown in the result section, the findings have led to the categorization of a variety of factors deemed to be representative of decision-making process in terms of oilseed crop production in Limpopo. The factors were grouped in terms of physical and economic characteristics, personal reasons and resource availability. Notwithstanding the fact that this categorization is arguably arbitrary owing to the subjective nature of a decision-making process, the interpretations and the presence of many overlaps within the categories of factors influencing crop investment decisions, similar studies have however been carried out (e.g. Liu et al., 2019a, 2019b; Greig, 2009) using a similar parameter. This therefore gives credibility to the overall results and addresses the aim of the study which was to determine the factors influencing crop investment decisions. The factors are discussed in the following paragraphs.

\subsection{Physical characteristics}

With regards to physical characteristics, climatic factors emerged as the principal determining factor influencing crop investment decisions. With regards to groundnut, the most physical factor affecting the production decision was rainfall, followed by temperature and floods. Temperature, rainfall and floods were the main determining factors for soybean, while it was temperature and floods played a key role when it came to sunflower. Referencing back to groundnuts, the findings indicated that water was another factor influencing the crop choice decision. Factor analysis indicated that flooding was the most critical factor influencing decisions focusing on crop choice decision. This might be as a result of the effect of floods (e.g. 1999/2000), which affected the area, as well as the close proximity of farms to rivers.

Even though relevant literature has shown that physical factors such as soil quality and the relief of the land, amongst others, influence crop production decision-making, in this study, these factors were however not deemed important from 


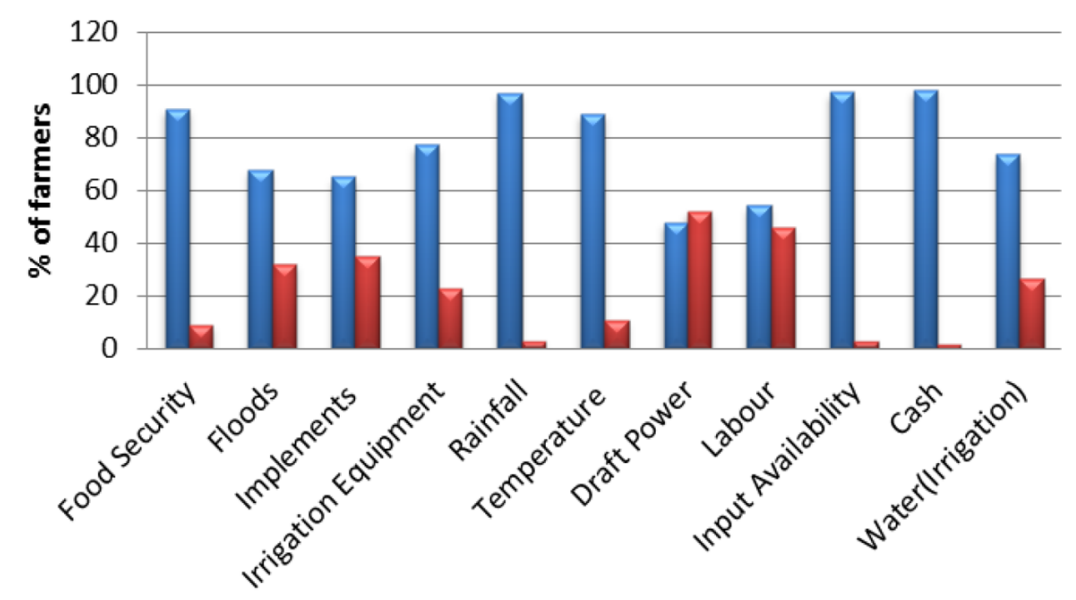

Q constraint groundnut

Non constraint groundnut

Factors

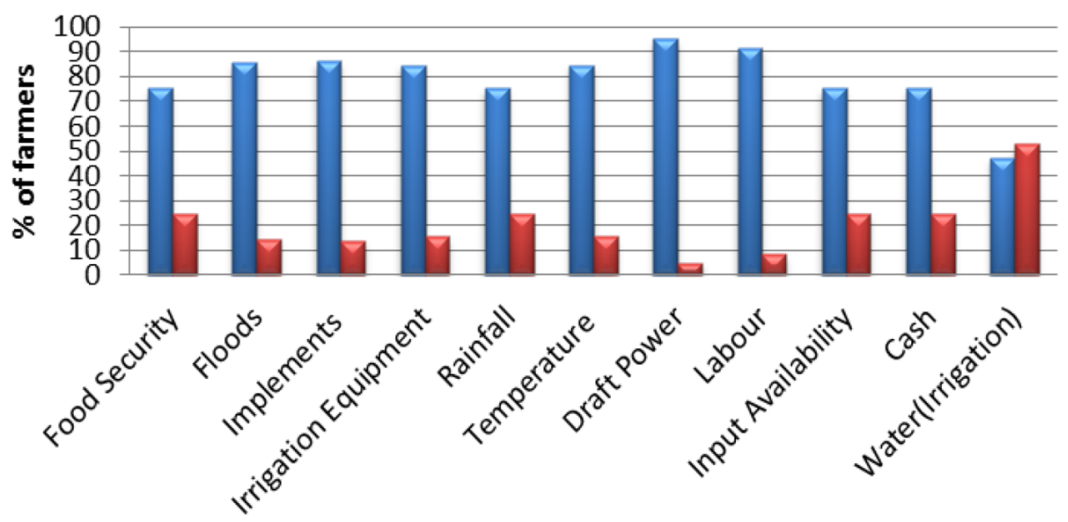

QConstraint sunflower

$\square$ Non Constraint sunflower

Factors

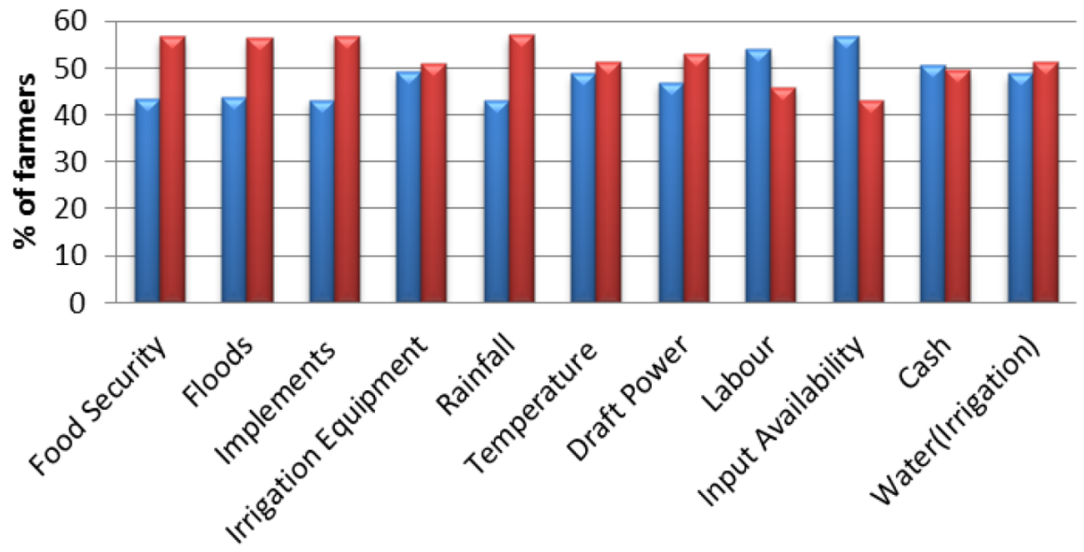

constraint soybean

Non constraint soybean

Factors

Fig. 3. Factors influencing crop production decisions for investments.

the initial pilot study, and as a result, were not added to the final survey. This might be because the farmers deemed physical properties such as soil relatively unimportant. Other studies have found this to be the case. For example, Ryder (2003) states that the existing agricultural patterns do not necessarily reflect land suitability and furthermore, in some cases, even farmers with profound knowledge of environmental requirements may establish a crop on inappropriate land for overriding socio-personal or economic reasons.

\subsection{Economics}

According to our analysis concerning economics, income is significant to the farmers' groundnut-planting decisions. 
It can be argued that farmers who get incomes from groundnut production are more likely to invest in its production in future. This might explain why a greater number of the farmers were producing groundnuts as shown in Figure 2. The results suggest that farmers aim to maximize profits and to plant crops with guaranteed income as seen in the case of groundnut. This result is corroborated by Liu et al. (2019a, 2019b) who reported that farm income was significant for the farmers' soybean planting behavior. Mandryk et al. (2014) also reported that farmers' practical decisions were mostly driven by economic profit. Farmers with more agriculture income were more likely to increase soybeans production. The issue of income is further seen in the case of soybean and sunflower. However, sunflower and soybean are seen here as new crops that the farmers are not very familiar with and hence might not want to risk producing as evidenced by the fact that only a small percentage of farmers were producing these crops. This view is supported by Caldas et al. (2014) who are of the opinion that the uncertainty of financial returns tended to steer farmer's away from certain crops especially if the crop is new and therefore unknown to them. The uncertainty surrounding the economic value of oilseed crops might stem from the fact that farmers are not cognizant of, or are unable to comprehend the prevailing economic forces at play when it comes to oilseed crops.

\subsection{Availability of resources}

The availability of resources will determine if a farmer decides to produce a certain type of crop. Where farmers struggle to get resources or where such resources are available but prohibitively expensive, the farmers will opt not to produce such crops. Figure 3 shows that in the case of groundnut, farmers struggled with implements (especially for harvesting), input (seeds, fertilizers, and pesticides) availability, irrigation equipment and labour. With regards to sunflower and soybean, implements, draft power, input availability, and labour affected the investment decision. These conclusions corroborate that of Liu et al. (2019a, 2019b), who showed that wre farmers are given incentives and subsidies for the production of a particular crop, there is increase in the production of such crops.

\subsection{Perception}

According to Caldas et al. (2014), farmers' perceptions play an important role in the willingness to plant biofuel crops. Personal reasons such as the familiarity with a crop have been shown to influence the crop production decision as shown in Figure 3. This might explain why groundnut is the major oilseed crop produced amongst the surveyed farmer. This is supported by Briggs (1985) and Greig (2009), who found that farmers' experience with the crop influenced the decision-making process. With regards to food security, sunflower is perceived rather unfavorably because the farmers' erroneous assertion that it does not contributing to food security, even though the crop can be sold and the returns used to acquire other consumable agricultural products like maize. Results from the factor analysis showed that food security is not the predominant factor in the decision-making process.

In considering the factors which influenced crop investment decisions in Limpopo amongst smallholder oilseed producing farmers, a combination of factors are at play, with floods, implements, temperature, rainfall, cash, irrigation equipment, and food security occupying the seats of honour in terms of the most crucial factors that determine which oilseed crop will be produced. It is therefore important to note that different factors are at play when it comes to choosing between various oilseed crops or between different grain crops. A range of factors will also be at play with regards to the processes involved in choosing between oilseed crops and grain crops.

\section{Conclusions and recommendations}

Oilseed crops have attracted much attention as potential renewable sources of raw material for substitutes to liquid fuel. With the rising focus on renewable energy sources, oilseed crops are good candidates as sources of biodiesel. Soybean, sunflower, and groundnut oils are amongst the seed oils available in South Africa and targeted for biodiesel production (BIS, 2007; FTDB, 2008). Production figures show a general decline in oilseed yield and a corresponding decrease of the area planted, in some years, in which some contributing factors can allude to investment decisions. The study revealed that most respondents' investment decisions were guided by physical and economic factors. It was further seen that decision factors were influenced by different variables, as farmers all have their motives, perceptions, beliefs, and preferences with regards to the choice of the oilseed produced. The implication for decision-making by smallholder farmers is a combination of factors operating in the area. Understanding factors influencing decision-making is important in order to explain current situations and to show how a situation might change under the influence of constraining and non-constraining factors.

The results open up many avenues for future research. For instance, are the factors underlying decision-making amongst oilseed smallholder farmers in Limpopo influential in other agricultural areas as well as amongst other grain producers? Do factors influencing oilseed production in Limpopo vary between smallholder and commercial farmers? Do challenges experienced by oilseed producing farmers in Limpopo differ as per agroecological zones and between smallholder and commercial farmers? Further study into the practical concerns of support type like input availability, implements availability raised in the discussion should be examined in greater depth.

This paper recommends a increase in sensitization and training of smallholder oil seed-producing farmers on the cost of production inputs, cost of production, production techniques of oil seeds. Furthermore, it recommends that farmers develop or improve upon the practice of incorporating newer crops for future production. In addition, it is recommended that other farmers supplement their income through the production of succession oilseed crops. This can be achieved through an extension service that would not only encourage the elderly to integrate the production of oilseeds into their farm management practices, but will also illustrate the cost implications of 
producing oilseeds. Moreover, governmental organizations should undertake initiatives that would attract more farmers to produce oilseed crops; for instance, by offering funding that is specifically earmarked for farming oilseed crops.

\section{Funding}

This work is funded through the University of Limpopo (UL) and the VLIR-UOS collaboration.

Conflicts of interest. The authors declare that they have no conflicts of interest in relation to this article.

\section{References}

Arunrat N, Wang C, Pumijumnong N, Sereenonchai S, Cai W. 2017. Farmers' intention and decision to adapt to climate change: a case study in the Yom and Nan basins, Phichit province of Thailand. $J$ Clean Prod 143: 672-685.

Asrat S, Yesuf M, Carlsson F, Wale E. 2010. Farmers' preferences for crop variety traits: lessons for on-farm conservation and technology adoption. Ecol Econ 69(12): 2394-2401.

Baiphethi MN, Jacobs PT. 2009. The contribution of subsistence farming to food security in South Africa. Agrekon 48(4): 459-482.

Biofuels Industrial Strategy (BIS) of the Republic of South Africa. 2007. Department of Minerals and Energy. Available from http:// www.info.gov.za/view/DownloadFileAction? id=77830 (accessed November 2019).

Botha M. 2006. Design and implementation of Capacity Development strategies. In: FAO, ed. Workshop Proceedings on Design and Implementation of Capacity Development Strategies: Final Report. 56th IEC Meeting and 19th Congress of the A South African case study International Commission on Irrigation and Drainage (ICID). Ch. 6, 67-88. Rome, Italy: Food and Agriculture Organization of the United Nations.

Briggs J. 1985. An exploratory study of farmers' choice of crops in Central Sudan. Transactions of the Institute of British Geographers: $170-180$.

Caldas MM, Bergtold JS, Peterson JM, et al. 2014. Factors affecting farmers' willingness to grow alternative biofuel feedstocks across Kansas. Biomass Bioener 66: 223-231.

Chen J, Yu Z, Ouyang J, Van Mensvoort M. 2006. Factors affecting soil quality changes in the North China Plain: a case study of Quzhou County. Agric Syst 91(3): 171-188.

Department of Agriculture, Forestry and Fisheries (DAFF). 2012. A framework for the development of smallholder farmers through cooperatives development. Pretoria: Department of Agriculture, Forestry and Fisheries.

Department of Agriculture, Forestry and Fisheries (DAFF). 2018. Abstract of agricultural statistics. South African Department of Agriculture, Forestry and Fisheries. Available from http://www. daff.gov.za/Daffweb3/Portals/0/Statistics\%20and\%20Economic \%20Analysis/Statistical\%20Information/Abstract\%202018.pdf.

Dube K. 2016. Implications of rural irrigation schemes on household economy. A case of Lower Gweru Irrigation Scheme, Zimbabwe. South African Journal of Agricultural Extension 44(1): 75-90.

Dury J, Garcia F, Reynaud A, Bergez J-E. 2013. Cropping-plan decision-making on irrigated crop farms: a spatio-temporal analysis. Eur J Agron 50: 1-10.

Free State Freight Transport Data Bank (FTDB). 2008. Grain and seed production. Available from http:/www.freetrans.gov.za/FTD/fs/ industries/grain_seeds/index.html (accessed November 2019).
Greig L. 2009. An analysis of the key factors influencing farmer's choice of crop, Kibamba Ward, Tanzania. J Agric Econ 60(3): 699-715.

Haile MG, Kalkuhl M, von Braun J. 2014. Inter- and intra-seasonal crop acreage response to international food prices and implications of volatility. Agric Econ 45(6): 693-710.

Harvest Choice. 2010. Available from http://harvestchoice.org/data/ aez-16-class.

Henderson AD, Asselin-Balençon AC, Heller M, Lessard L, Vionnet S, Jolliet O. 2017. Spatial variability and uncertainty of water use impacts from US feed and milk production. Environmental Science \& Technology 51(4): 2382-2391.

Huang PC. 1986. Small peasant economy and social change in North China. Beijing, China: Zhonghua Book Company.

Jaffe J. 1989. Land use, soil degradation, and farmer decision-making: a Sondeo report of Cavalier, Despa, Kols, and Saut Mathurine, Haiti. Port-au-Prince, Haiti.

Katundu MA, Mhina ML, Mbeiyererwa AG. 2014. Socio-economic factors limiting smallholder groundnut production in Tabora region. Available from http:/www.repoa.or.tz/documents/ REPOA_RR_14.1.pdf (accessed on 15 May 2018).

Khapayi M, Celliers P. 2016. Factors limiting and preventing emerging farmers to progress to commercial agricultural farming in the King William's Town area of the Eastern Cape Province, South Africa. S Afr J Agric Ext 44(1): 25-41.

Kinuthia KJ, Inot SK, Nakhone L. 2018. Factors influencing farmer's choice of crop production response strategies to climate change and variability in Narok East sub-county, Kenya. Journal of Natural Resources and Development 08: 69-77.

Krupnik TJ, Schulthess U, Ahmed ZU, McDonald AJ. 2017. Sustainable crop intensification through surface water irrigation in Bangladesh? A geospatial assessment of landscape-scale production potential. Land Use Policy 60: 206-222.

Lawas MCM, Luning HA. 1998. GIS and multivariate analysis of farmer's spatial crop decision behaviour. NJAS Wageningen Journal of Life Sciences 46(2): 193-207.

Liancui W, Honghui C. 2010. Positive study on the effect of grain subsidy policy on farmers' planting behavior. Technology Economics 6: 68-73.

Limpopo Department of Agriculture (LDA). 2012. The Mapping of Agricultural Commodity Production in the Limpopo province, South Africa.

Liu S, Zhang P, Marley B, Liu W. 2019a. The factors affecting farmers' soybean planting behavior in Heilongjiang Province, China. Agriculture 9(9): 188.

Liu S, Zhang P, Marley B, Liu W. 2019b. The factors affecting farmers' soybean planting behavior in Heilongjiang Province, China. Agriculture 9(9): 188.

Liu L. 2000. Labor location and agricultural land use in Jilin, China. Prof Geogr 52(1): 74-83.

Low A. 1986. Agricultural development in Southern Africa: farm household-economics and the food crisis. James Currey.

Mahon N, McGuire S, Islam MM. 2016. Why bother with Bere? An investigation into the drivers behind the cultivation of a landrace barley. J Rural Stud 45: 54-65.

Mandryk M, Reidsma P, Kanellopoulos A, Groot JC, van Ittersum MK. 2014. The role of farmers' objectives in current farm practices and adaptation preferences: a case study in Flevoland, the Netherlands. Reg Environ Change 14(4): 1463-1478.

Mukwevho R, Anim F. 2014. Factors affecting small scale farmers in accessing markets: a case study of cabbage producers in the Vhembe District, Limpopo Province of South Africa. J Hum Ecol 48(2): 219-225. 
Navarrete M, Le Bail M. 2007. SALADPLAN: a model of the decision-making process in lettuce and endive cropping. Agron Sustain Dev 27(3): 209-221. doi:10.1051/agro:2007009.

Negatu B, Vermeulen R, Mekonnen Y, Kromhout H. 2016. A method for semi-quantitative assessment of exposure to pesticides of applicators and re-entry workers: an application in three farming systems in Ethiopia. Ann Work Expo Health 60(6): 669-683. doi:10.1093/annhyg/mew022.

Oni SA, Nesamvuni AE, Odhiambo JJ, Dagada DC. 2012. Executive summary of a study of agricultural industry of Limpopo Province. South Africa: Centre for rural development: department of soil science.

Paul J, Sierra J, Causeret F, Guindé L, Blazy J-M. 2017. Factors affecting the adoption of compost use by farmers in small tropical Caribbean islands. J Clean Prod 142: 1387-1396.

Pereira L. 2017. Climate change impacts on agriculture across Africa. Oxford Research Encyclopedia of Environmental Science.

Popescu A, Alecu IN, Dinu TA, Stoian E, Condei R, Ciocan H. 2016. Farm structure and land concentration in Romania and the European Union's agriculture. Agriculture and Agricultural Science Procedia 10: 566-577.

Ravnborg HM, Rubiano JE. 2001. Farmers' decision making on land use - the importance of soil conditions in the case of Río Cabuyal watershed, Colombia. Geografisk Tidsskrift-Danish Journal of Geography 101(1): 115-130.

Ryder R. 2003. Local soil knowledge and site suitability evaluation in the Dominican Republic. Geoderma 111(3-4): 289-305.

Saito K, Linquist B, Keobualapha B, Shiraiwa T, Horie T. 2006. Farmers' knowledge of soils in relation to cropping practices: a case study of farmers in upland rice based slashand-burn systems of northern Laos. Geoderma 136(1-2): 64-74.

Schulze RE, Durand W. 2016. Maize yields over South Africa under historical and projected future climatic conditions. In: Schulze RE, ed. Handbook for farmers, officials and other stakeholders on adaptation to climate change in the agriculture sector within South Africa. Section C: Crops and Climate Change, Chapter C2. pp. 22.

Seo SN, Mendelsohn R. 2008. An analysis of crop choice: adapting to climate change in South American farms. Ecol Econ 67(1): 109-116.
Statistics South Africa. 2010. Mid-year population estimates. Available from http://www.scielo.org.za/scielo.php?script=sci nlinks\&ref= 3619992\&pid=S0301-603X201600010000300033\&旾g=en.

Statistics South Africa. 2012. Census 2011. Available from http:// www.scielo.org.za/scielo.php?script $=$ sci_nlinks\&ref= 3619994\&pid=S0301-603X201600010000300034\&lng=en.

Thamaga-Chitja JM, Morojele P. 2014. The context of smallholder farming in South Africa: towards a livelihood asset building framework. J Hum Ecol 45(2): 147-155.

Trochim W.M. 2006. Nonprobability sampling. Research methods Knowledge Base 1(1): 1-10.

Tuckman BW. 2000. Conducting educational research, 5th ed. Fort Worth, TX: Harcourt Brace.

Van Niekerk P. 2002. Product development as part of a positioning strategy for the hunting industry in the Eastern Cape. DTech thesis. Port Elizabeth: Port Elizabeth Technikon.

Wang T, Luri M, Janssen L, et al. 2017. Determinants of motives for land use decisions at the margins of the Corn Belt. Ecol Econ 134: 227-237.

Wauters E, Mathijs E. 2014. The adoption of farm level soil conservation practices in developed countries: a meta-analytic review. Int J Agric Resour Gov Ecol 10(1): 78-102.

Wu L, Cai H. 2010. Positive study on the effect of grain subsidy policy on farmers' planting behavior. Technology Economics 29 (6): 68-73.

Wu J, Murphy F, Garvey J, Ma W. 2015. The role of market participants in agricultural futures markets. Outl Agric 44(2): 97-108.

Wu W, Yang P, Meng C, et al. 2008. An integrated model to simulate sown area changes for major crops at a global scale. Sci China D Earth Sci 51(3): 370-379.

Yang L, Liu M, Lun F, Yuan Z, Zhang Y, Min Q. 2017. An analysis on crops choice and its driving factors in agricultural heritage systems - a case of Honghe Hani Rice Terraces System. Sustainability 9(7): 1162.

Yu J, Smith A, Sumner DA. 2016. The effects of the premium subsidies in the US federal crop insurance program on crop acreage (No. 333-2016-14232).

Zhang Y, Li X, Song W, Zhai L. 2016. Land abandonment under rural restructuring in China explained from a cost-benefit perspective. $J$ Rural Stud 47: 524-532.

Cite this article as: Kephe PN, Ayisi KK, Petja BM, Mulaudzi AP, Mabitsela KE. 2020. Factors influencing the production of oilseed crops among smallholder farmers in Limpopo Province. OCL 27: 41. 